\title{
Crystal Packing and Supramolecular Motifs in Four Phenoxyalkanoic Acid Herbicides-Low-Temperature Redeterminations
}

\author{
Lesław Sieroń, Joanna Kobyłecka, and Anna Turek \\ Institute of General and Ecological Chemistry, Technical University of Łódż, Żeromskiego 116, 90-924 Łódź, Poland
}

Correspondence should be addressed to Lesław Sieroń, leslaw.sieron@p.lodz.pl

Received 30 September 2010; Revised 7 February 2011; Accepted 7 March 2011

Academic Editor: Ken Shimizu

Copyright () 2011 Lesław Sieron et al. This is an open access article distributed under the Creative Commons Attribution License, which permits unrestricted use, distribution, and reproduction in any medium, provided the original work is properly cited.

\begin{abstract}
A low-temperature redetermination by X-ray crystallography of four phenoxyalkanoic acid herbicides, 4-chloro-2-methylphenoxyacetic acid (MCPA), rac-2-(4-chloro-2-methylphenoxy)propionic acid (MCPP), 2,4-dichlorophenoxyacetic acid (2,4-D), and 2,4-dichlorophenoxybutyric acid (2,4-DB), allowed the supramolecular structures of these compounds to be precisely described in terms of $\mathrm{C} \cdots \mathrm{O} / \mathrm{C}-\mathrm{H} \cdots \pi$ interactions. The geometric parameters of the redetermined structures agree with those previously reported, but with improved precision.
\end{abstract}

\section{Introduction}

Phenoxyalkanoic acids, having methyl and/or chlorine substituent groups in the ortho and meta positions of the benzene ring, are known selective herbicides, used to control broadleaf weeds in crop production. The first compound of this group, used already in 1944 in agriculture for weed control, was 2,4-dichlorophenoxyacetic acid (2,4-D). The physico- and biological properties of this group of compounds have been the subject of extensive studies [1-3]. As part of our wider study on metal complexes with herbicides of the phenoxyalkanoic acid series and on the herbicidesoil-plant interaction $[4,5]$, we report here structure redeterminations at $90 \mathrm{~K}$ of 4-chloro-2-methylphenoxyacetic acid $\left(\mathrm{C}_{9} \mathrm{H}_{9} \mathrm{ClO}_{3}\right.$; MCPA; compound 1), rac-2-(4-chloro-2methylphenoxy)propionic acid $\left(\mathrm{C}_{10} \mathrm{H}_{11} \mathrm{ClO}_{3}\right.$; MCPP; compound 2), 2,4-dichlorophenoxyacetic acid $\left(\mathrm{C}_{8} \mathrm{H}_{6} \mathrm{Cl}_{2} \mathrm{O}_{3} ; 2,4\right.$ $\mathrm{D}$; compound 3), and 2,4-dichlorophenoxybutyric acid $\left(\mathrm{C}_{10} \mathrm{H}_{10} \mathrm{Cl}_{2} \mathrm{O}_{3} ; 2,4-\mathrm{DB}\right.$; compound 4$)$. The structures of the compounds 1-3 were determined using X-ray diffraction data [6-9], collected at ambient temperature many years ago, with inaccurate refined or missing hydrogen atoms. The structure of $\mathbf{4}$ was previously determined at $173 \mathrm{~K}$. In result, weak hydrogen interactions could not be precisely defined, and supramolecular structures have not been fully analyzed. These kind of bonds have been found to play an important role in many biological structures, as proteins, polypeptides, and drug-binding interactions [10-12].

\section{Experimental}

Structures of the compounds $\mathbf{1} \mathbf{- 4}$ were determined by using single-crystal X-ray diffraction methods, using the Bruker AXS Smart APEX-II CCD 3-circle diffractometer with MonoCap capillary and monochromated Mo K $\alpha$ radiation $(\lambda=0.71073 \AA, 50 \mathrm{kV}, 32 \mathrm{~mA})$ at $90 \mathrm{~K}$. Data collection and data reduction were done with the SMART [13] and SAINT-PLUS [14] programs. All structures were solved by direct methods and refined by the full-matrix least-squares methods on $\mathrm{F}^{2}$ with anisotropic thermal for all nonhydrogen atoms. All hydrogen atoms were located in difference Fourier syntheses and were refined freely. The final geometrical calculations were carried out using the PLATON program [15]. The relevant crystal data and experimental details are summarized in Table 1. Figures were drawn using Mercury [16] and SHELXTL [14] programs. 
TABLe 1: Crystal data and structural refinement details for compounds 1-4.

\begin{tabular}{|c|c|c|c|c|}
\hline & 1 & 2 & 3 & 4 \\
\hline Empirical formula & $\mathrm{C}_{9} \mathrm{H}_{9} \mathrm{ClO}_{3}$ & $\mathrm{C}_{10} \mathrm{H}_{11} \mathrm{ClO}_{3}$ & $\mathrm{C}_{8} \mathrm{H}_{6} \mathrm{Cl}_{2} \mathrm{O}_{3}$ & $\mathrm{C}_{10} \mathrm{H}_{10} \mathrm{Cl}_{2} \mathrm{O}_{3}$ \\
\hline Formula weight & 200.61 & 214.64 & 221.03 & 249.08 \\
\hline Crystal system & Triclinic & Monoclinic & Triclinic & Triclinic \\
\hline Space group & $P-1$ & $P 2_{1} / c$ & $P-1$ & $P-1$ \\
\hline$a(\AA)$ & $5.0867(3)$ & $4.2261(3)$ & $7.1246(2)$ & $7.4845(4)$ \\
\hline$b(\AA)$ & $7.7824(4)$ & $6.8196(5)$ & $7.8399(2)$ & $8.7892(5)$ \\
\hline$c(\AA)$ & $12.2134(7)$ & $35.176(3)$ & $8.8991(3)$ & $9.3777(4)$ \\
\hline$\alpha\left({ }^{\circ}\right)$ & $73.933(1)$ & 90 & $90.654(1)$ & $81.0720(14)$ \\
\hline$\beta\left(^{\circ}\right)$ & $84.610(2)$ & $91.801(2)$ & $104.565(1)$ & $69.5538(13)$ \\
\hline$\gamma\left({ }^{\circ}\right)$ & $77.009(1)$ & 90 & $110.527(1)$ & $65.3163(12)$ \\
\hline$V\left(\AA^{3}\right), Z$ & $452.45(4), 2$ & $1013.28(13), 4$ & $447.82(2), 2$ & $525.18(5), 2$ \\
\hline$d_{\text {calc }}\left(\mathrm{g} / \mathrm{cm}^{3}\right)$ & 1.472 & 1.407 & 1.639 & 1.575 \\
\hline$F(000)$ & 208 & 448 & 224 & 256 \\
\hline Temperature $(\mathrm{K})$ & 90 & 90 & 90 & 90 \\
\hline Radiation type, wavelength $(\AA)$ & Mo K $\alpha, 0.71073$ & Mo K $\alpha, 0.71073$ & Mo K $\alpha, 0.71073$ & Mo K $\alpha, 0.71073$ \\
\hline Absorption coeff. $\left(\mathrm{mm}^{-1}\right)$ & 0.391 & 0.354 & 0.692 & 0.600 \\
\hline Theta range $\left(^{\circ}\right)$ & $1.7-27.0$ & $2.3-25.0$ & $2.4-27.0$ & $2.3-27.0$ \\
\hline Limiting indices, $h, k, l$ & $\begin{aligned}-6 & \rightarrow 6 \\
-9 & \rightarrow 9 \\
-15 & \rightarrow 15\end{aligned}$ & $\begin{aligned}-5 & \rightarrow 5 \\
-8 & \rightarrow 8 \\
-41 & \rightarrow 41\end{aligned}$ & $\begin{aligned}-9 & \rightarrow 9 \\
-10 & \rightarrow 10 \\
-11 & \rightarrow 11\end{aligned}$ & $\begin{aligned}-9 & \rightarrow 9 \\
-11 & \rightarrow 11 \\
-11 & \rightarrow 11\end{aligned}$ \\
\hline Reflections collected & 9864 & 17135 & 9777 & 11607 \\
\hline Unique reflections & $1974\left[R_{\mathrm{int}}=0.0233\right]$ & $1756\left[R_{\mathrm{int}}=0.0208\right]$ & $1928\left[R_{\mathrm{int}}=0.0148\right]$ & $2287\left[R_{\mathrm{int}}=0.0148\right]$ \\
\hline Completeness to $\theta_{\max }$ & $99.7 \%$ & $99.7 \%$ & $99.2 \%$ & $99.6 \%$ \\
\hline Data/Restraints/Parameters & $1974 / 0 / 154$ & $1756 / 0 / 171$ & $1928 / 0 / 143$ & $2287 / 0 / 176$ \\
\hline Goodness-of-fit on $F^{2}$ & 1.13 & 1.27 & 1.07 & 1.03 \\
\hline Final $R$ indices $[\mathrm{I}>2 \sigma(\mathrm{I})]$ & $\begin{array}{c}R=0.0308 \\
w R^{2}=0.0860\end{array}$ & $\begin{array}{c}R=0.0347 \\
w R^{2}=0.0811\end{array}$ & $\begin{array}{c}R=0.0199 \\
w R^{2}=0.0523\end{array}$ & $\begin{array}{c}R=0.0206 \\
w R^{2}=0.0583\end{array}$ \\
\hline Final $R$ indices [all data] & $\begin{array}{c}R=0.0316 \\
w R^{2}=0.0864\end{array}$ & $\begin{array}{c}R=0.0349 \\
w R^{2}=0.0812\end{array}$ & $\begin{array}{c}R=0.0201 \\
w R^{2}=0.0525\end{array}$ & $\begin{array}{c}R=0.0209 \\
w R^{2}=0.0585\end{array}$ \\
\hline $\begin{array}{l}\text { Largest diff. peak and hole } \\
\left(\mathrm{e} \cdot \AA^{-3}\right)\end{array}$ & $0.398,-0.272$ & $0.274,-0.228$ & $0.407,-0.193$ & $0.404,-0.217$ \\
\hline
\end{tabular}

Compound 1: weight $=1 /\left[\sigma^{2}\left(F_{0}^{2}\right)+(0.0418 P)^{2}+0.2516 P\right]$, where $P=\left(\max \left(F_{0}^{2}, 0\right)+2 F_{c}^{2}\right) / 3$, Compound 2: weight $=1 /\left[\sigma^{2}\left(F_{0}^{2}\right)+(0.0189 P)^{2}+1.0828 P\right]$, where $P=\left(\max \left(F_{0}^{2}, 0\right)+2 F_{c}^{2}\right) / 3$, Compound 3: weight $=1 /\left[\sigma^{2}\left(F_{0}^{2}\right)+(0.0235 P)^{2}+0.2140 P\right]$, where $P=\left(\max \left(F_{0}^{2}, 0\right)+2 F_{c}^{2}\right) / 3$, Compound 4: weight $=1 /\left[\sigma^{2}\left(F_{0}^{2}\right)+(0.0329 P)^{2}+0.2198 P\right]$, where $P=\left(\max \left(F_{0}^{2}, 0\right)+2 F_{c}^{2}\right) / 3$.

\section{Results}

The unit-cell dimensions and atomic coordinates show that the phase is the same at both $90 \mathrm{~K}$ and ambient temperature for all redetermined structures. All described molecules associate via strong head-to-head carboxyl $\mathrm{O}-\mathrm{H}$. . O hydrogen bonds, forming typical carboxylic acid cyclic dimers about centres of symmetry into $R_{2}^{2}(8)$ rings $[17,18]$. The compounds also crystallize with one independent molecule in the asymmetric unit.

The oxoacetic acid side chain in compound 1 adopts an extended planar conformation, with a C1-O3-C7-C8 torsion angle of $170.89(12)^{\circ}$ (Figure 1).

Apart for the strong head-to-head hydrogen-bonded ring motif common to carboxylic acids [O1-H1 . . $\left.\mathrm{O} 2^{-x-1,-y+2,-z}\right]$, the molecules are also connected into dimers, forming 14-membered rings via C6-H6 . . $\mathrm{O} 1^{-x,-y+1,-z}$ interactions with symmetry-related molecules. The close contact between the $\mathrm{Cl} 4$ and the aryl methyl C9 group $\left[\mathrm{Cl} 14 \cdot \mathrm{C} 9^{1+x,-1+y, z}=3.412(2) \AA\right]$ is also observed (Figure 2). All three types of interactions are mutually coplanar and parallel to a crystallographic $\left(\begin{array}{lll}1 & 1 & -2\end{array}\right)$ plane. A methylene group participates in a C7-H71 $\cdots \pi$ interaction, with a benzene ring of an adjacent layer, and these serve to connect polymeric planes into a three-dimensional network.

In the structure of compound 2 , the side chain $\mathrm{C} 1-$ O3-C7-C8 torsion angle of $84.6(2)^{\circ}$ indicates a synclinal conformation of the chain (Figure 3 ).

The main intermolecular interactions are the $R_{2}^{2}(8)$ dimers involving strong hydrogen bonds $\mathrm{O} 1-\mathrm{H} 1 \cdots$ $\mathrm{O} 2^{-x+1,-y,-z}$ between the carboxyl groups of adjacent molecules. Another hydrogen-bonding interaction involves 


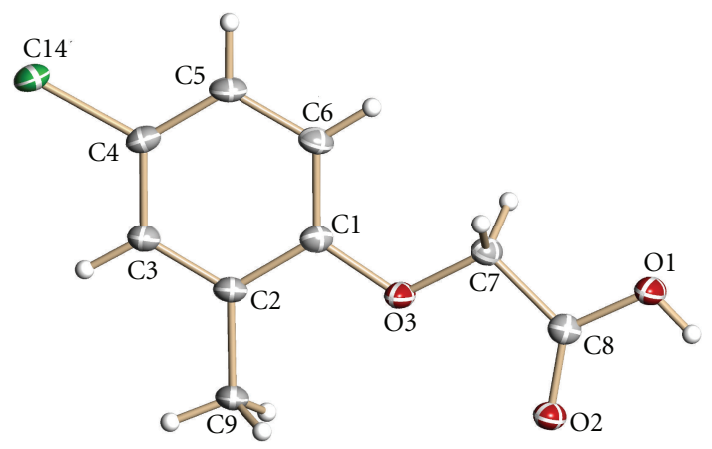

FIgURE 1: A molecular diagram of $\mathbf{1}$, showing the atom numbering scheme. Displacement ellipsoids are drawn at the $50 \%$ probability level. $\mathrm{H}$ atoms are shown as small spheres of arbitrary radii.

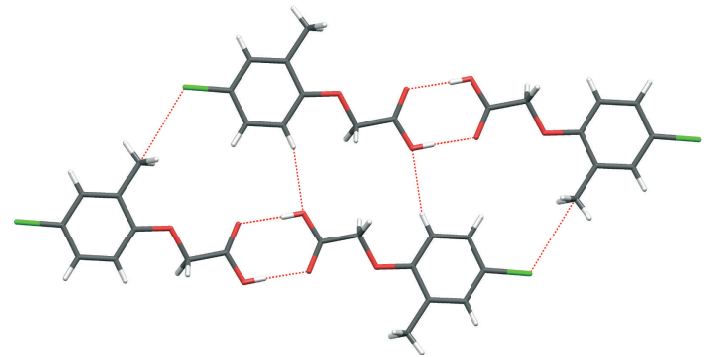

Figure 2: A fragment of the structure of 1, showing the twodimensional polymeric framework formed through the intermolecular $\mathrm{O}-\mathrm{H} \cdots \mathrm{O}$ hydrogen bonds and $\mathrm{C}-\mathrm{H} \cdots \mathrm{O}$ and $\mathrm{C}-\mathrm{Cl} \cdots \mathrm{C}$ contacts, shown as dashed lines.

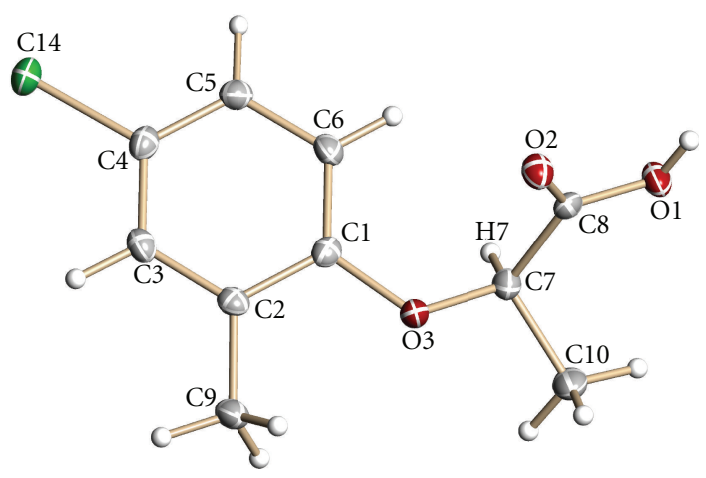

FIGURE 3: A molecular diagram of 2, showing the atom numbering scheme. Displacement ellipsoids are drawn at the $50 \%$ probability level. $\mathrm{H}$ atoms are shown as small spheres of arbitrary radii.

a methine $\mathrm{H} 7$ atom that is engaged in bifurcated symmetrical C7-H7 . . O contacts to carboxyl O1 and ether $\mathrm{O} 3$ atoms of neighbouring molecule, and making a graph-set motif of $\mathrm{C}_{1}^{2}(3)\left[R_{1}^{2}(5)\right]$, running along $a$ axis (Figure 4 ). A bifurcation is confirmed by the sum of angles about atom $\mathrm{H} 7$, which is $359.7(10)^{\circ}[19]$.

Replacement of the 2-methyl ring substituent group in $\mathbf{1}$ by a chlorine atom in 3 results in a different conformation

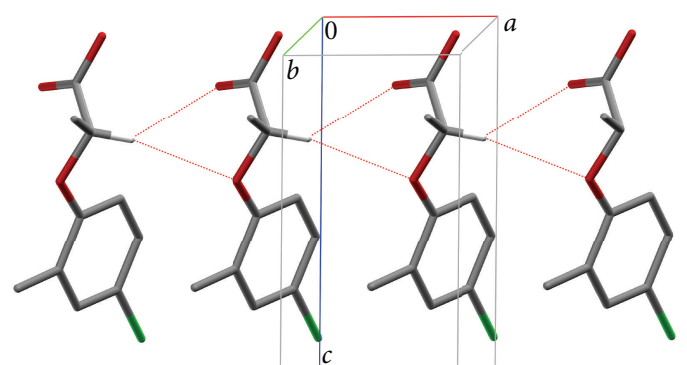

FIGURE 4: The molecular packing of the compound 2, showing atoms of a neighbouring molecule, making a $C_{1}^{2}(3)\left[R_{1}^{2}(5)\right]$ graph set motif, running along the $a$ axis. Dashed lines indicate the hydrogenbonding interactions. All the hydrogens except for the methine H7 have been removed for clarity.

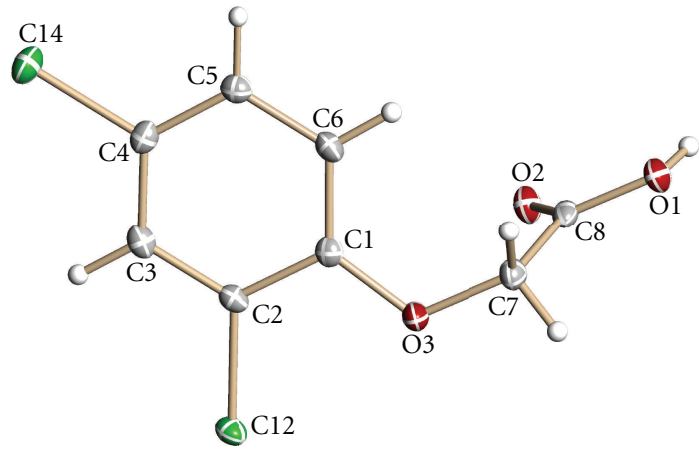

FIGURE 5: A molecular diagram of 3, showing the atom-numbering scheme. Displacement ellipsoids are drawn at the $50 \%$ probability level. $\mathrm{H}$ atoms are shown as small spheres of arbitrary radii.

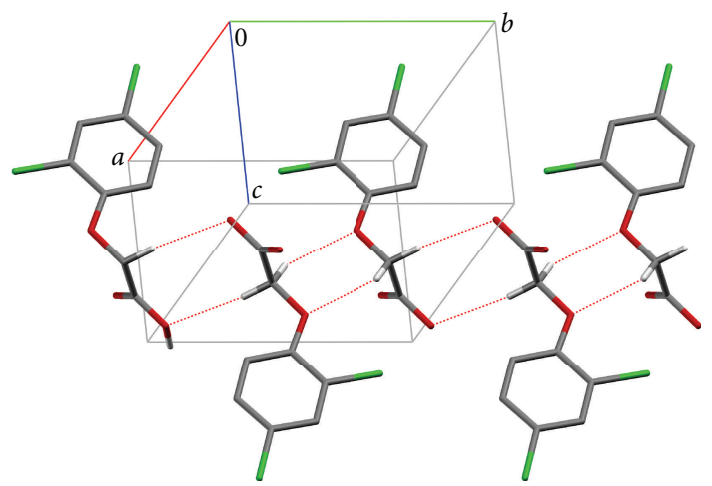

Figure 6: The molecular packing of the compound 3, showing the alternating $R_{2}^{2}(6)$ and $R_{2}^{2}(8)$ rings, running along the $b$ axis. Dashed lines indicate the hydrogen-bonding interactions. All the hydrogens except H71 and H72 have been removed for clarity.

of the chain that is synclinal, with a $\mathrm{C} 1-\mathrm{O} 3-\mathrm{C} 7-\mathrm{C} 8$ torsion angle of $81.02(13)^{\circ}$ (Figure 5).

A methylene group is engaged here in two relatively strong $\mathrm{C}-\mathrm{H} \cdots \mathrm{O}$ interactions with carboxyl $\mathrm{O} 1$ and ether $\mathrm{O} 3$ atoms, forming in effect two centrosymmetric $R_{2}^{2}(6)$ and $R_{2}^{2}(8)$ rings (Figure 6). The $\mathrm{C} 3-\mathrm{H} 3 \cdots \mathrm{O}^{-x+1,-y+1,-z+1}$ contact and its symmetry-related counterpart join two another molecules, generating an $R_{2}^{2}(14)$ graph-set motif. The 


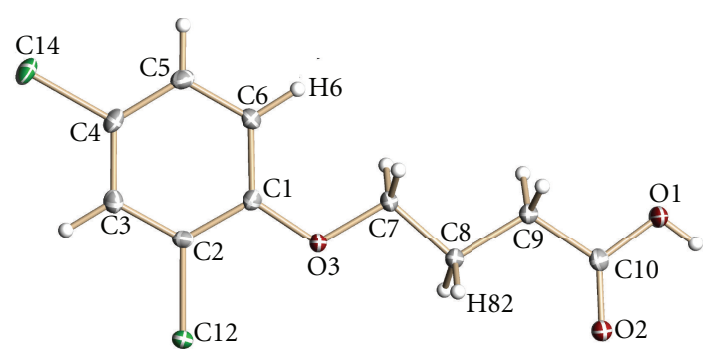

Figure 7: A molecular diagram of 4, showing the atom-numbering scheme. Displacement ellipsoids are drawn at the $50 \%$ probability level. $\mathrm{H}$ atoms are shown as small spheres of arbitrary radii.

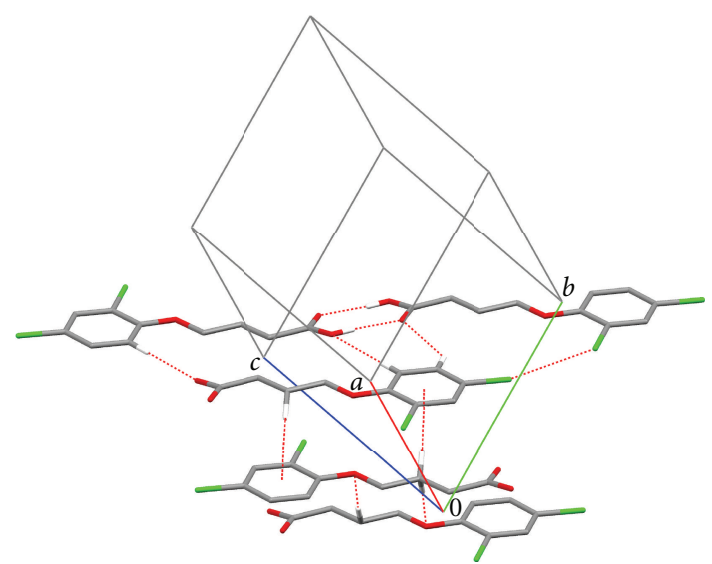

Figure 8: The intermolecular $\mathrm{O}-\mathrm{H} \cdots \mathrm{O}, \mathrm{C}-\mathrm{H} \cdots \mathrm{O}, \mathrm{C}-\mathrm{H} \cdots \pi$ and $\mathrm{Cl} \cdot \mathrm{Cl}$ contacts in compound 4 , shown as dashed lines. All the hydrogens except those not involved in interactions have been removed for clarity.

structure shows also a significant contact between adjacent benzene rings with a centroid separation distance of 3.6505(7) $\AA$, and the $\mathrm{C} 2-\mathrm{Cl} 2 \cdots C g 1^{1-x, 1-y, 1-z}[C g 1$ is the centroid of ring $\mathrm{C}(1-6)]$ contact with a $\mathrm{Cl} \cdots \pi$ separation of $3.5610(6) \AA$.

Compound $\mathbf{4}$ is conformationally similar to $\mathbf{1}$ and adopts the planar conformation, confirmed by the torsion angles of C1-O3-C7-C8 = 179.20(10), O3-C7-C8-C9 = -178.25(9), and $\mathrm{C} 7-\mathrm{C} 8-\mathrm{C} 9-\mathrm{C} 10=173.83(11)^{\circ}$ (Figure 7).

The neighbouring molecules are connected via $\mathrm{O} 1-$ $\mathrm{H} 1 \cdots \mathrm{O} 2^{-x+1,-y-1,-z+2}, \mathrm{C} 5-\mathrm{H} 5 \cdots \mathrm{O} 2^{x-1, y+1, z} \mathrm{C} 6-\mathrm{H} 6 \cdots$ $\mathrm{O} 1{ }^{-x,-y,-z+2}$ hydrogen bonds and a short $\mathrm{Cl} 2 \cdots \mathrm{Cl} 2^{1-x,-y,-z}$ nonbonding interaction of 3.2976(4) $\AA$ which are mutually coplanar and parallel to crystallographic plane $\left(\begin{array}{lll}2 & 2 & 1\end{array}\right)$. Further interactions in the crystal structure of $\mathrm{C} 7-$ $\mathrm{H} 71 \cdots \mathrm{Cl}^{-x,-y+1,-z+1}, \mathrm{C} 8-\mathrm{H} 81 \cdots \mathrm{O}^{-x+1,-y,-z+1}$ and C8$\mathrm{H} 82 \cdots C g 1^{-x,-y,-z+1}[C g 1$ is the centroid of ring $\mathrm{C}(1-6)]$ connect adjacent polymeric layers into a three-dimensional supramolecular network (Figure 8).

The comparison of the all analyzed structures shows that the $\mathrm{C} 2-\mathrm{Cl} 2$ bond lengths of $1.7323(11)$ and $1.7371(10)^{\circ}$ in 3 and 4 are distinctly shorter than $\mathrm{C} 4-\mathrm{Cl} 4$, ranging from $1.7416(11)$ to $1.746(2)^{\circ}$ in $\mathbf{1 - 4}$. The bond lengths in the carboxylic acid group range from 1.2171(13) to 1.2211(18) $\AA$
TABle 2: Selected bond lengths $(\AA)$ and angles $\left({ }^{\circ}\right)$ for compounds 1-4.

\begin{tabular}{|c|c|c|}
\hline \multicolumn{3}{|c|}{1} \\
\hline $\mathrm{Cl} 4-\mathrm{C} 4$ & & $1.746(2)$ \\
\hline $\mathrm{O} 1-\mathrm{C} 8$ & & $1.313(2)$ \\
\hline $\mathrm{O} 2-\mathrm{C} 8$ & & $1.219(2)$ \\
\hline $\mathrm{O} 3-\mathrm{C} 1$ & & $1.385(2)$ \\
\hline $\mathrm{O} 3-\mathrm{C} 7$ & & $1.418(2)$ \\
\hline $\mathrm{C} 1-\mathrm{O} 3-\mathrm{C} 7-\mathrm{C} 8$ & & $84.6(2)$ \\
\hline $\mathrm{O} 3-\mathrm{C} 7-\mathrm{C} 8-\mathrm{O} 1$ & & $177.84(15)$ \\
\hline \multicolumn{3}{|c|}{2} \\
\hline $\mathrm{Cl} 4-\mathrm{C} 4$ & & $1.746(2)$ \\
\hline $\mathrm{O} 1-\mathrm{C} 8$ & & $1.313(2)$ \\
\hline $\mathrm{O} 2-\mathrm{C} 8$ & & $1.219(2)$ \\
\hline $\mathrm{O} 3-\mathrm{C} 1$ & & $1.385(2)$ \\
\hline $\mathrm{O} 3-\mathrm{C} 7$ & & $1.418(2)$ \\
\hline $\mathrm{C} 1-\mathrm{O} 3-\mathrm{C} 7-\mathrm{C} 8$ & & $84.6(2)$ \\
\hline $\mathrm{O} 3-\mathrm{C} 7-\mathrm{C} 8-\mathrm{O} 1$ & & $177.84(15)$ \\
\hline \multicolumn{3}{|c|}{3} \\
\hline $\mathrm{Cl} 2-\mathrm{C} 2$ & & $1.7323(11)$ \\
\hline $\mathrm{Cl} 4-\mathrm{C} 4$ & & $1.7416(11)$ \\
\hline $\mathrm{O} 1-\mathrm{C} 8$ & & $1.3194(13)$ \\
\hline $\mathrm{O} 2-\mathrm{C} 8$ & & $1.2183(15)$ \\
\hline $\mathrm{O} 3-\mathrm{C} 1$ & & $1.3677(13)$ \\
\hline $\mathrm{O} 3-\mathrm{C} 7$ & & $1.4157(13)$ \\
\hline $\mathrm{C} 1-\mathrm{O} 3-\mathrm{C} 7-\mathrm{C} 8$ & & $81.02(13)$ \\
\hline $\mathrm{O} 3-\mathrm{C} 7-\mathrm{C} 8-\mathrm{O} 1$ & & $-179.94(9)$ \\
\hline \multicolumn{3}{|c|}{4} \\
\hline $\mathrm{Cl} 2-\mathrm{C} 2$ & & $1.7371(10)$ \\
\hline $\mathrm{Cl} 4-\mathrm{C} 4$ & & $1.7443(11)$ \\
\hline $\mathrm{O} 1-\mathrm{C} 10$ & & $1.3250(13)$ \\
\hline $\mathrm{O} 2-\mathrm{C} 10$ & & $1.2171(13)$ \\
\hline $\mathrm{O} 3-\mathrm{C} 1$ & & $1.3584(13)$ \\
\hline $\mathrm{O} 3-\mathrm{C} 7$ & & $1.4393(12)$ \\
\hline $\mathrm{C} 1-\mathrm{O} 3-\mathrm{C} 7-\mathrm{C} 8$ & & $179.20(10)$ \\
\hline $\mathrm{O} 3-\mathrm{C} 7-\mathrm{C} 8-\mathrm{C} 9$ & & $-178.25(10)$ \\
\hline C7-C8-C9-C10 & & $173.83(11)$ \\
\hline C8-C9-C10-O1 & & $-169.26(11)$ \\
\hline
\end{tabular}

and from $1.313(2)$ to $1.3250(13) \AA$ for $\mathrm{C}=\mathrm{O}$ and $\mathrm{C}-\mathrm{OH}$, respectively. Selected bond distances and torsion angles are listed in Table 2. Hydrogen-bonding geometries are listed in Table 3.

\section{Conclusion}

A low-temperature redetermination by X-ray crystallography of four phenoxyalkanoic acids have been carried out. Investigations of the interactions shown the typical carboxylic acid cyclic $\mathrm{O}-\mathrm{H} \cdots$ O hydrogen bonds between adjacent molecules. However, their conformations and molecular packing in the crystals are quite different, which can be 
TABle 3: Close contacts of hydrogen bond type [ $\AA$ and $\left.{ }^{\circ}\right]$ for compounds 1-4.

\begin{tabular}{|c|c|c|c|c|}
\hline $\mathrm{D}-\mathrm{H} \cdots \mathrm{A}$ & $\mathrm{D}-\mathrm{H}$ & $\mathrm{H} \cdots \mathrm{A}$ & $\mathrm{D} \cdots \mathrm{A}$ & $\mathrm{D}-\mathrm{H} \cdots \mathrm{A}$ \\
\hline \multicolumn{5}{|c|}{1} \\
\hline $\mathrm{O} 1-\mathrm{H} 1 \cdots \mathrm{O} 2^{\mathrm{i}}$ & $0.82(2)$ & $1.81(2)$ & $2.6342(15)$ & $178(3)$ \\
\hline $\mathrm{C} 6-\mathrm{H} 6 \cdots \mathrm{O} 1^{\mathrm{ii}}$ & $0.90(2)$ & $2.56(2)$ & $3.4253(19)$ & $161.6(19)$ \\
\hline $\mathrm{C} 7-\mathrm{H} 71 \cdots \mathrm{Cg} 1^{\mathrm{iii}}$ & $0.98(2)$ & $2.66(2)$ & $3.4207(16)$ & $134.4(13)$ \\
\hline \multicolumn{5}{|c|}{2} \\
\hline $\mathrm{O} 1-\mathrm{H} 1 \cdots \mathrm{O} 2^{\text {iv }}$ & $0.82(3)$ & $1.83(3)$ & $2.645(2)$ & $176(3)$ \\
\hline $\mathrm{C} 7-\mathrm{H} 7 \cdots \mathrm{O} 2^{\mathrm{v}}$ & $0.97(2)$ & $2.72(2)$ & $3.474(2)$ & $135.6(14)$ \\
\hline $\mathrm{C} 7-\mathrm{H} 7 \cdots \mathrm{O}^{\mathrm{v}}$ & $0.97(2)$ & $2.71(2)$ & $3.647(2)$ & $164.0(15)$ \\
\hline \multicolumn{5}{|c|}{3} \\
\hline $\mathrm{O} 1-\mathrm{H} 1 \cdots \mathrm{O} 2^{\mathrm{vi}}$ & $0.82(2)$ & $1.81(2)$ & $2.6330(13)$ & $178.2(13)$ \\
\hline $\mathrm{C} 3-\mathrm{H} 3 \cdots \mathrm{O} 2^{\mathrm{vii}}$ & $0.95(2)$ & $2.54(2)$ & $3.4335(14)$ & $157.2(13)$ \\
\hline $\mathrm{C} 7-\mathrm{H} 71 \cdots \mathrm{O} 3^{\mathrm{viii}}$ & $0.94(1)$ & $2.47(1)$ & $3.2454(14)$ & $140.0(12)$ \\
\hline $\mathrm{C} 7-\mathrm{H} 72 \cdots \mathrm{O} 1^{\text {iv }}$ & $0.97(2)$ & $2.54(2)$ & $3.5073(15)$ & $173.0(12)$ \\
\hline \multicolumn{5}{|c|}{4} \\
\hline $\mathrm{O} 1-\mathrm{H} 1 \cdots \mathrm{O} 2^{\mathrm{ix}}$ & $0.81(2)$ & $1.85(2)$ & $2.6578(12)$ & $172.4(18)$ \\
\hline $\mathrm{C} 5-\mathrm{H} 5 \cdots \mathrm{O} 2^{\mathrm{x}}$ & $0.93(1)$ & $2.72(1)$ & $3.4078(13)$ & $131.0(11)$ \\
\hline $\mathrm{C} 6-\mathrm{H} 6 \cdots \mathrm{O}^{\mathrm{xi}}$ & $0.96(2)$ & $2.74(2)$ & $3.6937(13)$ & $179.4(14)$ \\
\hline C7-H71 $\cdots \mathrm{Cl}^{\mathrm{xii}}$ & $0.99(2)$ & $2.89(2)$ & $3.7830(14)$ & $151.3(12)$ \\
\hline $\mathrm{C} 8-\mathrm{H} 81 \cdots \mathrm{O} 3^{\mathrm{xiii}}$ & $0.97(1)$ & $2.78(2)$ & $3.7390(13)$ & $176.4(11)$ \\
\hline $\mathrm{C} 8-\mathrm{H} 82 \cdots \mathrm{Cg}^{\mathrm{xiv}}$ & $0.98(2)$ & $2.70(2)$ & $3.5369(13)$ & $143.5(12)$ \\
\hline \multicolumn{5}{|c|}{ 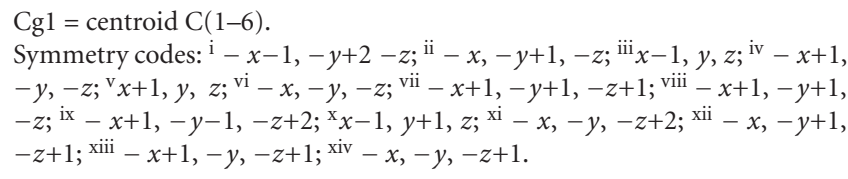 } \\
\hline
\end{tabular}

explained by the influence of significant $\mathrm{C}-\mathrm{H} \cdots \mathrm{O}, \mathrm{C}-$ $\mathrm{H} \cdots \pi, \mathrm{C}-\mathrm{Cl} \cdots \mathrm{C}$ intermolecular contacts, forming supramolecular structures. The additional contacts of the $\pi \cdots \pi$ and $\mathrm{C}-\mathrm{Cl} \cdots \pi$ type have been observed in compound 3 , and the $\mathrm{Cl} \cdots \mathrm{Cl}$ type in compound 4 .

\section{References}

[1] G. G. Bond and R. Rossbacher, "A review of potential human carcinogenicity of the chlorophenoxy herbicides MCPA, MCPP, and 2,4-DP," British Journal of Industrial Medicine, vol. 50, no. 4, pp. 340-348, 1993.

[2] P. Mai, O. Stig Jacobsen, and J. Aamand, "Mineralization and co-metabolic degradation of phenoxyalkanoic acid herbicides by a pure bacterial culture isolated from an aquifer," Applied Microbiology and Biotechnology, vol. 56, no. 3-4, pp. 486-490, 2001.

[3] J. R. de Lipthay, S. R. Sørensen, and J. Aamand, "Effect of herbicide concentration and organic and inorganic nutrient amendment on the mineralization of mecoprop, 2,4-D and 2,4,5-T in soil and aquifer samples," Environmental Pollution, vol. 148, no. 1, pp. 83-93, 2007.

[4] J. Kobyłecka and A. Turek, "Complexes of lead(II), copper(II), zinc(II) and cadmium(II) with 2,4-dichlorophenoxyacetic acid," Annals of the Polish Chemical Society, vol. 2, pp. 462-466, 2003.

[5] J. Kobyłecka, B. Ptaszyński, R. Rogaczewski, and A. Turek, "Phenoxyalkanoic acid complexes. Part I. Complexes of
lead(II), cadmium(II) and copper(II) with 4-chloro-2-methylphenoxyacetic acid (MCPA)," Thermochimica Acta, vol. 407, no. 1-2, pp. 25-31, 2003.

[6] G. Smith and C. H. L. Kennard, "4-Chloro-2-methylphenoxyacetic acid," Structure Communications, vol. 10, pp. 295299, 1981.

[7] G. Smith, C. H. L. Kennard, A. H. White, and P. G. Hodgson, "(+-)-2-(4-Chloro-2-methylphenoxy)propionic acid (mecoprop)," Acta Crystallographica Section B, vol. 36, pp. 992-994, 1980.

[8] G. Smith, C. H. L. Kennard, and A. H. White, "Herbicides. Part I. Crystal structure of 2,4-D (2,4-dichlorophenoxy-acetic acid)," Journal of the Chemical Society, Perkin Transactions 2, no. 7, pp. 791-792, 1976.

[9] G. Smith, S. M. Shariff, E. J. O’Reilly, and C. H. L. Kennard, " $\gamma$-phenoxybutanoic acids and their metal(II) complexes. The crystal structures of 4-(4-chlorophenoxy)butanoic acid, 4-(2,4-dichlorophenoxy)butanoic acid, diaquabis [4-phenoxybutanoato] nickel(II), and cobalt(II) and diaquabis[4-(4chlorophenoxy)butanoato]nickel(II)," Polyhedron, vol. 8, no. 1, pp. 39-43, 1989.

[10] Z. S. Derewenda, L. Lee, and U. Derewenda, "The occurrence of $\mathrm{C}-\mathrm{H} \cdots \mathrm{O}$ hydrogen bonds in proteins," Journal of Molecular Biology, vol. 252, no. 2, pp. 248-262, 1995.

[11] G. R. Desiraju and T. Steiner, The Weak Hydrogen Bond in Structural Chemistry and Biology, Oxford University Press, Oxford, UK, 1999.

[12] M. Brandl, M. S. Weiss, A. Jabs, J. Sühnel, and R. Hilgenfeld, "C-H. $\cdot \pi$-interactions in proteins," Journal of Molecular Biology, vol. 307, no. 1, pp. 357-377, 2001.

[13] Bruker, SMART for WNT/2000, Version 5.630, Bruker AXS Inc., Madison, Wis, USA, 2002.

[14] Bruker, SAINT-Plus (Version 6.45) and SHELXTL (Version 6.14), Bruker AXS Inc., Madison, Wis, USA, 2003.

[15] A. L. Spek, "Single-crystal structure validation with the program PLATON," Journal of Applied Crystallography, vol. 36, no. 1, pp. 7-13, 2003.

[16] C. F. Macrae, P. R. Edgington, P. McCabe et al., "Mercury: visualization and analysis of crystal structures," Journal of Applied Crystallography, vol. 39, no. 3, pp. 453-457, 2006.

[17] M. C. Etter, J. C. MacDonald, and J. Bernstein, "Graph-set analysis of hydrogen-bond patterns in organic crystals," Acta Crystallographica Section B, vol. 46, pp. 2256-262, 1990.

[18] L. Leiserowitz, "Molecular packing modes. Carboxylic acids," Acta Crystallographica Section B, vol. 32, pp. 775-802, 1976.

[19] G. A. Jeffrey and W. Saenger, Hydrogen Bonding in Biological Structures, Springer, New York, NY, USA, 1991. 


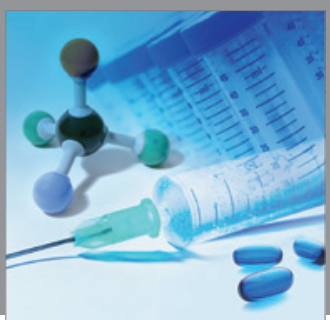

International Journal of

Medicinal Chemistry

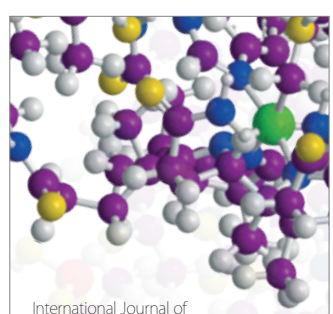

Carbohydrate Chemistry

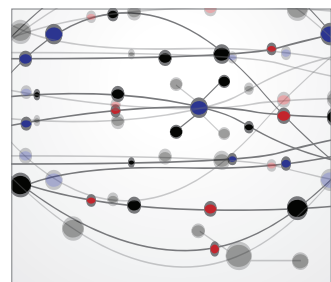

The Scientific World Journal
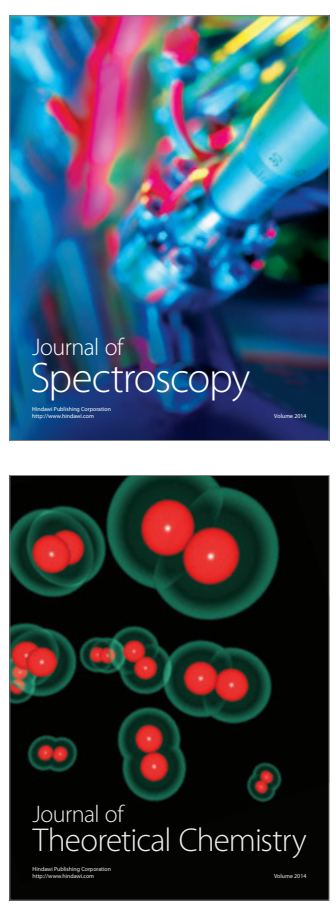
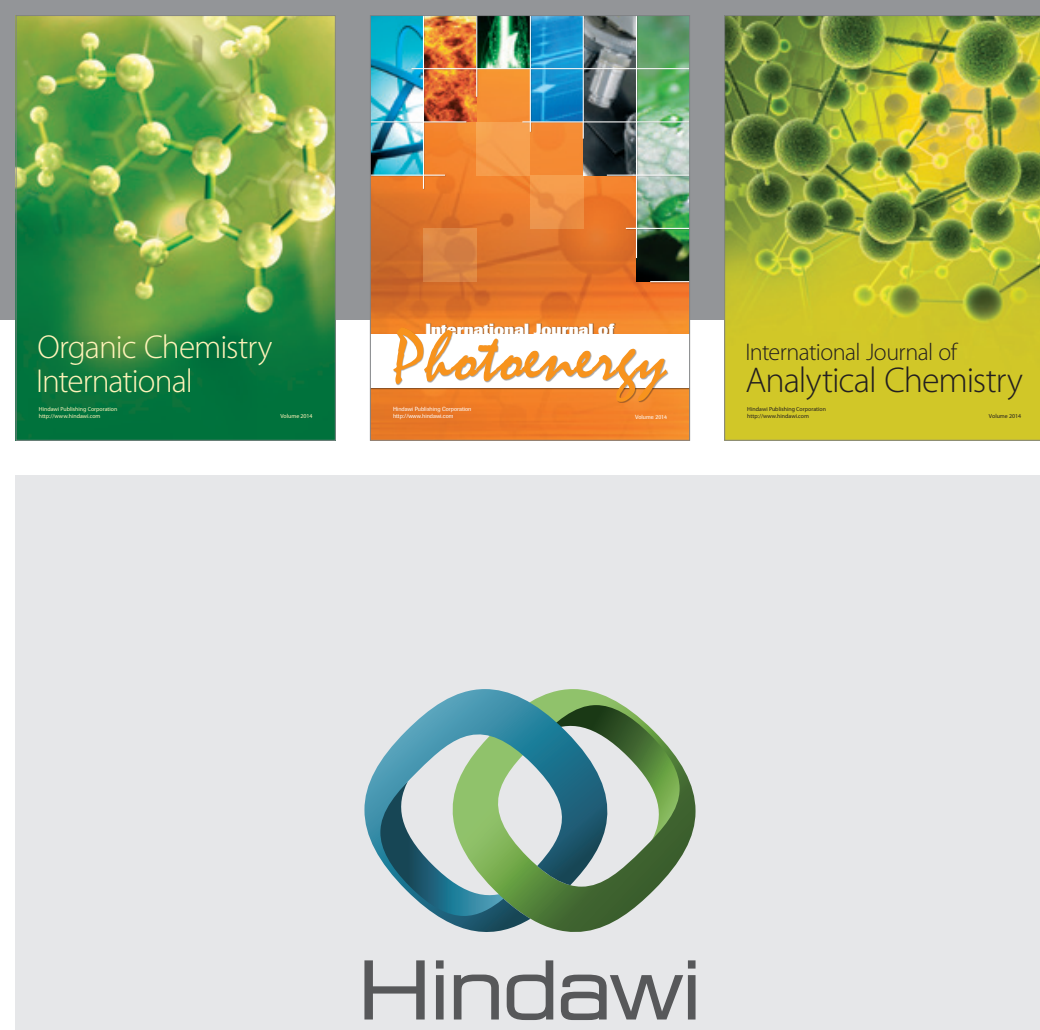

Submit your manuscripts at

http://www.hindawi.com
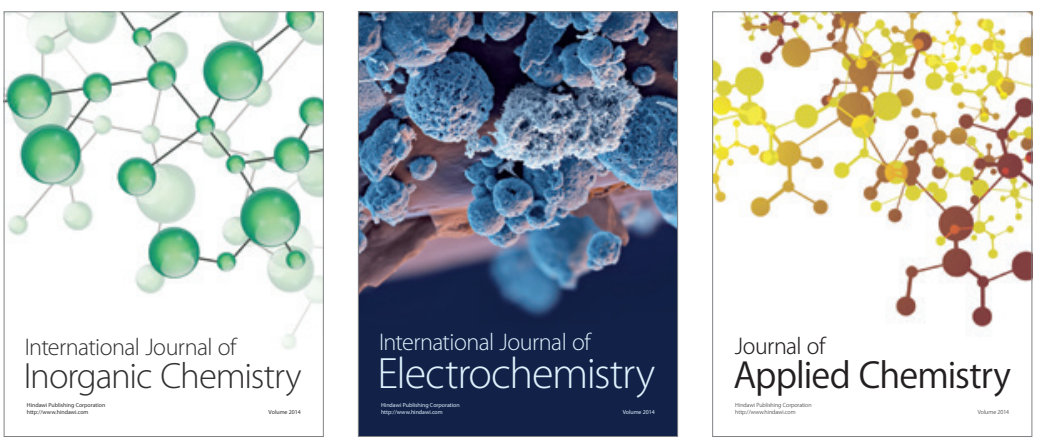

Journal of

Applied Chemistry
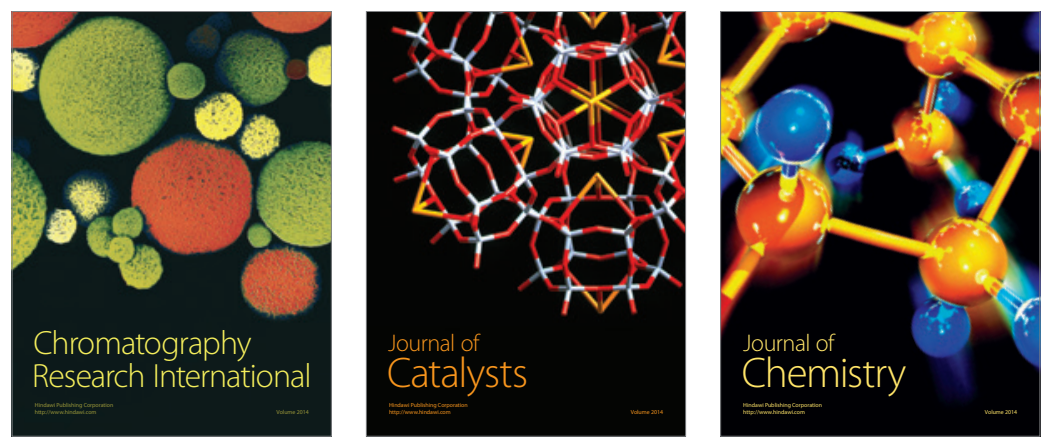
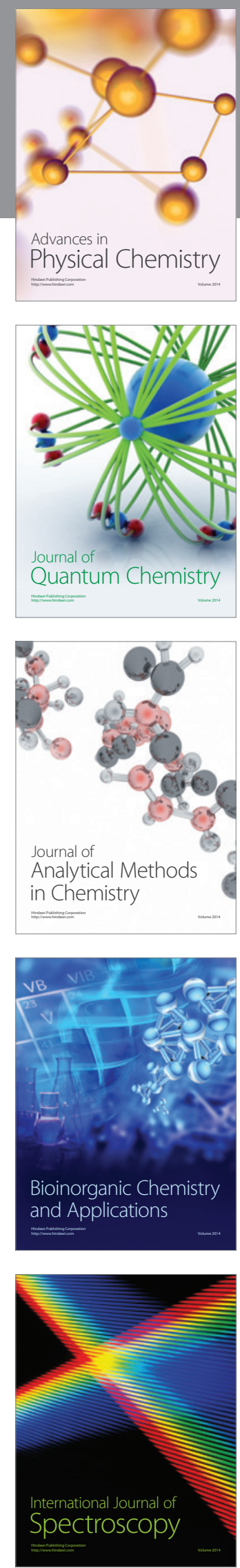